\title{
ROLE OF AP-1 TRANSCRIPTIONAL FACTOR IN DEVELOPMENT OF OXIDATIVE AND NITROSATIVE STRESS IN PERIODONTAL TISSUES DURING SYSTEMIC INFLAMMATORY RESPONSE
}

\author{
A. M. YELINS'KA, O. Ye. AKIMOV凶, V. O. KOSTENKO \\ Ukrainian Medical Stomatological Academy, Poltava, Ukraine; \\ 凶e-mail: riseofrevan5@gmail.com
}

Received: 04 August 2018; Accepted: 13 December 2018

\begin{abstract}
Chronic systemic inflammatory response syndrome (SIRS) underlies many diseases (sepsis, atherosclerosis, diabetes mellitus). According to research data of recent years the key role in the development of SIRS is played by the activation of various nuclear transcription factors. The work was aimed at studying the role of such transcription factor as activator protein 1 (AP-1) in the development of oxidative and nitrosative stress in soft periodontal tissues during chronic systemic inflammatory response (SIRS). The experiment was carried out on 24 the Wistar rats. We induced SIRS by bacterial lipopolysaccharide of Salmonella typhi $(0.4 \mu \mathrm{g} / \mathrm{kg})$ intraperitoneal injection. We studied changes in the functioning of the nitric oxide (NO) cycle, the production of superoxide anion radical $\left(\mathrm{O}_{2}^{-}\right)$and the activity of antioxidant enzymes in soft periodontal tissues homogenate. We used SR11302 as an AP-1 inhibitor (15 mg/kg) for 2 months. We established that during the SIRS modeling, the activity of antioxidant enzymes in soft periodontal tissues decreased with a simultaneous increase in the production of $\mathrm{O}_{2}^{--}$. SIRS elevated the production of NO by inducible NO-synthase (iNOS) and nitrite reductases. The nonoxidative cleavage of L-arginine under this condition was also increased. The concentration of peroxynitrite (ONOO-) was shown to be elevated more than 2-fold. The inhibition of AP-1 by SR11302 normalized the functional state of the $\mathrm{NO}$ cycle, reduced $\mathrm{O}_{2}^{--}$production and restored the activity of antioxidant enzymes. In this way, under SIRS conditions, "vicious circle" of ONOO- formation is formed. SIRS in soft periodontal tissues poses a threat of oxidative and nitrosative stress development. Usage of AP-1 activation inhibitor SR11302 breaks "vicious circle" of ONOO- formation.
\end{abstract}

Keywords: periodontium, systemic inflammatory response, activator protein 1 (AP-1), superoxide anion radical, nitric oxide cycle.

$\mathrm{B}$ one R. C. at el. proposed a concept of the chronic systemic inflammatory response syndrome (SIRS) in order to describe the complex response of organism to such irritants as infection, trauma and burns [1]. SIRS leads to a significant, ten-fold or hundred-fold increase in the level of such cytokines in the blood plasma as tumor necrosis factor- $\alpha$ (TNF- $\alpha$ ), interleukin-1 (IL-1), interleukin-6 (IL-6), interleukin-10 (IL-10) and others. During the chronic SIRS the level of the blood plasma cytokines increases in about 2-4 times. SIRS precedes the development and determines the severity of hypertension [2].
Bayani M. et al. showed in their work the dependence of the severity of changes in the periodontium on the level of cytokines in diabetes mellitus and other systemic diseases, associated with SIRS [3].

Redox-sensitive nuclear transcription factors play a key role in the SIRS development. Li X. and co-authors demonstrated the role of activation of the nuclear transcription factor $\kappa \mathrm{B}(\mathrm{NF}-\kappa \mathrm{B})$ and mitogen-activated protein kinases (MAPK) in the development of SIRS [4]. The AP-1 transcription factor is a dimeric complex that includes members of the Jun and Fos protein families. At the moment, the

(C) 2019 Yelins'ka A. M. et al. This is an open-access article distributed under the terms of the Creative Commons Attribution License, which permits unrestricted use, distribution, and reproduction in any medium, provided the original author and source are credited. 
role of activator protein-1 (AP-1) in the development of SIRS-induced oxidative and nitrosative stress in periodontal tissues has not been sufficiently studied.

The aim of this work is to study the role of AP-1 in the development of oxidative and nitrosative stress in soft periodontal tissues under the SIRS.

\section{Materials and Methods}

We carried out the study on 24 mature male Wistar rats weighing 200-220 g. Bioethical committee of Ukrainian Medical Stomatological Academy approved all experimental procedures with experimental animals. Animals were divided into 3 groups: control animals (8), SIRS group (8), and animals (8), which received the AP-1 inhibitor, namely (2E,4E,6Z,8Z)-3-methyl-7-(4-methylphenyl)-9(2,6,6-trimethylcyclohexen-1-yl)nona-2,4,6,8-tetraenoic acid (SR11302) in a dose of $15 \mathrm{mg} / \mathrm{kg}$ (iAP-1 group).

The experiment lasted 2 months. The chronic systemic inflammatory response was induced by injection of bacterial lipopolysaccharide of Salmonella typhi (Pyrogenalum, Medgamal, Russia) intraperitoneally in a dose of 4 minimal pyrogenic doses (MPD) per $1 \mathrm{~kg}$ of animal body weight that corresponds to $0.4 \mu \mathrm{g} / \mathrm{kg}$. We administered Pyrogenalum three times during the $1^{\text {st }}$ week of the experiment to trigger an acute systemic inflammatory response; then in order to develop and maintain a chronic systemic inflammatory response Pyrogenalum was administered once a week for 1 month [5]. The animals from the SIRS group continued to receive Pyrogenalum once a week until the end of the experiment.

After the development of SIRS, the animals from the iAP-1 group received injections of an aqueous solution of SR11302 intraperitoneally twice a week for a month.

All animals from the control group received $0.9 \%$ (weight/volume) $\mathrm{NaCl}$ solution intraperitoneally 3 times during the $1^{\text {st }}$ week, and then once a week for 2 months. The volume of the injected liquid did not exceed $0.2 \mathrm{ml}$.

We removed animals from the experiment under ether anesthesia by decapitation. We carried out all biochemical studies in $10 \%$ periodontal tissues homogenate.

Determination of total NO-synthases, arginases, nitrate and nitrite reductases activities and concentration of peroxynitrite was performed as described in [6]. In addition to method [6] to determine the activity of constitutive NO-synthases (cNOS) we modified procedure proposed in [6]. The modification consists from adding $0.1 \mathrm{ml}$ of $1 \%$ (weight/ volume) solution of aminoguanidine hydrochloride (98\% Sigma Aldrich) to the first aliquot $(0.2 \mathrm{ml}$ of $10 \%$ homogenate, $2.5 \mathrm{ml} 0.1 \mathrm{M}$ Tris-buffer, $0.3 \mathrm{ml}$ $320 \mathrm{mM} \mathrm{L}$-arginine water solution and $0.1 \mathrm{ml} 1 \mathrm{mM}$ NADPH solution) and changing incubation time to $60 \mathrm{~min}$. The rest of the method was carried out as described in [6]. The activity of inducible NO-synthase (EC 1.14.13.39, iNOS) was evaluated by subtracting the cNOS activity from the overall activity of NO-synthases (EC 1.14.13, NOS).

We evaluated the production of the superoxide radical anion $\left(\mathrm{O}_{2}^{\circ}\right)$ by estimation of concentration of diformazan, formed in reaction of $\mathrm{O}_{2}^{-{ }^{-}}$with nitroblue tetrazolium (IUPAC: 2-[2-methoxy-4-[3-methoxy4-[3-(4-nitrophenyl)-5-phenyltetrazol-2-ium-2-yl] phenyl]phenyl]-3-(4-nitrophenyl)-5-phenyltetrazol-2ium) [7]. In order to estimate influence of cellular organelles (mitochondria and endoplasmic reticulum) and tissue phagocytes specific reaction conditions described in [7] were used. The activity of superoxide dismutase (EC 1.15.1.1, SOD) was determined according to the recommendations [8]; the activity of catalase (EC 1.11.1.6, CAT) was assessed by the method [9]. Protein concentration was determined by Biurette method.

The results were analyzed for normality by the Shapiro-Wilk test. Then, non-parametric analysis by Kruskal-Wallis test and comparison of groups by the Mann-Whitney test were carried out. The difference between groups was considered statistically significantwhen $P<0.05$.

\section{Results and Discussion}

SIRS notably increased production of $\mathrm{O}_{2}{ }^{-}$from all its sources in periodontal tissues homogenate (Table 1). Basal production of $\mathrm{O}_{2}{ }^{--}$increased by $16.9 \%$. $\mathrm{O}_{2}{ }^{--}$production by the mitochondrial electron transport chain (ETC) elevated in 1.47 times. $\mathrm{O}_{2}{ }^{-}$production under SIRS conditions by microsomal ETC and NO-synthase increased by $61.6 \%$. Periodontal phagocytes increased $\mathrm{O}_{2}^{--}$production by $19.3 \%$.

SIRS was accompanied by decreased activity of antioxidant enzymes. The activity of SOD and CAT was reduced by 32.8 and $9.5 \%$ respectively.

The production of nitric oxide (NO) by L-arginine-dependent pathway was elevated by 3.9 times under SIRS conditions (Table 2), activity of nitrite reductases increased by $34.7 \%$, nitrate reductases increased their activity by $55.0 \%$. cNOS activity 
Ta ble 1. $\mathrm{O}_{2}^{\cdot-}$ production and antioxidant enzymes activity in rat periodontium under conditions of chronic systemic inflammatory response and usage of AP-1 inhibitor $(M \pm m, n=8)$

\begin{tabular}{l|c|c|c}
\hline \multirow{2}{*}{ Parameters } & \multicolumn{3}{c}{ Groups } \\
\cline { 2 - 4 } & Control & SIRS & SIRS + AP-1 inhibitor \\
\hline $\begin{array}{l}\text { Production of } \mathrm{O}_{2}^{*-} \text {, nmol/s per g } \\
\text { of tissue: }\end{array}$ & & \\
$\quad$ Basic & $0.77 \pm 0.03$ & $0.90 \pm 0.01^{*}$ & $0.81 \pm 0.033^{\#}$ \\
From microsomal ETC & $18.64 \pm 0.57$ & $30.13 \pm 0.29^{*}$ & $18.87 \pm 0.57^{\#}$ \\
From mitochondrial ETC & $11.73 \pm 1.44$ & $28.95 \pm 0.46^{*}$ & $11.83 \pm 1.42^{\#}$ \\
From phagocytes & $1.14 \pm 0.02$ & $1.36 \pm 0.01^{*}$ & $1.17 \pm 0.02^{\#}$ \\
\hline SOD activity, c.u. & $8.32 \pm 0.45$ & $5.59 \pm 0.56^{*}$ & $8.01 \pm 0.54^{\#}$ \\
\hline Catalase activity, $\mu$ katal/g of tissue & $0.241 \pm 0.006$ & $0.218 \pm 0.005^{*}$ & $0.239 \pm 0.005^{\#}$ \\
\hline *Data is significantly different from control group $(P<0.05) ;{ }^{*}$ data is significantly different from chronic systemic \\
inflammation response group $(P<0.05)$
\end{tabular}

Ta b le 2. The functioning of the nitric oxide cycle in rats periodontium under conditions of chronic systemic inflammatory response and usage of AP-1 inhibitor $(M \pm m, n=8)$

\begin{tabular}{l|c|c|c}
\hline \multirow{2}{*}{ Parameters } & \multicolumn{3}{c}{ Groups } \\
\cline { 2 - 4 } & Control & SIRS & SIRS + AP-1 inhibitor \\
\hline NOS activity, $\mathrm{nmol}\left(\mathrm{NO}_{2}^{-}\right) / \mathrm{min} \cdot \mathrm{mg}$ of protein: & & & \\
$\quad$ Total & $0.61 \pm 0.16$ & $2.39 \pm 0.24^{*}$ & $0.61 \pm 0.17^{\#}$ \\
cNOS & $0.38 \pm 0.14$ & $0.48 \pm 0.06$ & $0.37 \pm 0.14$ \\
iNOS & $0.25 \pm 0.04$ & $1.91 \pm 0.19^{*}$ & $0.24 \pm 0.04^{\#}$ \\
\hline ONOO- concentration, $\mu \mathrm{mol} / \mathrm{g}$ of tissue & $0.67 \pm 0.20$ & $1.41 \pm 0.13^{*}$ & $0.71 \pm 0.23^{\#}$ \\
\hline
\end{tabular}

Total arginase activity, nmol (L-ornithine)/

min.mg of protein

$1.05 \pm 0.16 \quad 4.05 \pm 0.27^{*} \quad 1.00 \pm 0.18^{\#}$

Total nitrate reductase activity, $\mathrm{nmol}\left(\mathrm{NO}_{3}^{-}\right) /$

min $\cdot m g$ of protein

$2.89 \pm 0.48 \quad 4.48 \pm 0.56^{*}$

$2.74 \pm 0.35^{\#}$

Total nitrite reductase activity, $\mathrm{nmol}\left(\mathrm{NO}_{2}^{-}\right) /$ min $\cdot \mathrm{mg}$ of protein

$2.77 \pm 0.35 \quad 3.73 \pm 0.22 *$

$2.53 \pm 0.38^{\#}$

*Data is significantly different from control group $(P<0.05)$; \#data is significantly different from chronic systemic inflammation response group $(P<0.05)$

did not show statistically significant changes, while the iNOS activity increased by 7.6 times. Arginase activity (EC 3.5.3.1) increased by 3.9 times. SIRS enhances the reduction of nitrates to nitrites by 1.6 times. The concentration of peroxynitrite ( $\left.\mathrm{ONOO}^{-}\right)$ was twice as much when compared with the control group.

The inhibition of AP-1 during the SIRS modeling reduced basic $\mathrm{O}_{2}^{--}$production by $10 \%$. Production of $\mathrm{O}_{2}{ }^{--}$by mitochondrial and microsomal ETC was reduced by $37.4 \%$ and $59.1 \%$, respectively. Usage of SR11302 slowed down (by $14.0 \%$ ) $\mathrm{O}_{2}{ }^{--}$production by phagocytes of periodontal tissues. SOD ac- tivity under conditions of AP-1 inactivation during SIRS increased by $43.3 \%$. CAT activity increased by $9.6 \%$.

Using SR11302 reduced overall NOS activity by $73.6 \%$. iNOS activity dropped by $87.4 \%$. There were no changes in cNOS activity as compared with the SIRS modeling group. Inhibition of AP-1 reduced the $\mathrm{ONOO}^{-}$concentration by 2.0 times. Arginases activity decreased by 4.0 times. Nitrate reductases activity decreased by 1.63 times, nitrite reductases activity decreased by $32.17 \%$.

Mechanisms of oxidative-nitrosative stress development in periodontium during SIRS. Increased 
$\mathrm{O}_{2}{ }^{--}$production may be considered as a result of increased activity of arginases, which according to Rabelo L.A. et al., are pro-oxidants [10]. $K_{\mathrm{m}}$ for L-arginine of arginase I and II (approximately $10 \mathrm{mmol} / \mathrm{l})$ [11], which is much higher than $K_{\mathrm{m}}$ for L-arginine of different NOS isoforms (approximately $5 \mu \mathrm{mol} / 1$ for iNOS and $3 \mu \mathrm{mol} / 1$ for eNOS) [12]. Therefore excessive arginase activation can lead to L-arginine deficiency for cNOS and they may shift to $\mathrm{O}_{2}^{--}$production instead of $\mathrm{NO}$ production. $V_{\max }{ }^{\prime}$ $K_{\mathrm{m}}$ for L-arginine of both iNOS and arginases are close so competition between them affects iNOS less than it affects nNOS or eNOS isofrms. According to the results obtained, cNOS activity does not change during SIRS modeling, thus, an increase in the $\mathrm{O}_{2}^{--}$ production by microsomal ETC is not associated with the cNOS substrate deficiency. A characteristic feature of our SIRS model is the long-term administration of bacterial lipopolysaccharide that leads to hypercytokinemia (increased IL-1 and TNF- $\alpha$ ). Cao Y. reported that stimulation of chondrocytes with pro-inflammatory cytokines (IL-1 and TNF- $\alpha$ ) results in an increase in the production of reactive oxygen species (ROS) by cell mitochondria [13]. IL-1 $\beta$ can enhance the activity of microsomal NADPH oxidase and lead to over-production of ROS by the microsomal ETC [14]. Elevated $\mathrm{O}_{2}{ }^{--}$production can lead to oxidative stress development in periodontal tissues.

During SIRS modeling in periodontal tissues we observed excessive NO production caused by iNOS activation. Enhanced activity of iNOS may be the result of Pyrogenalum administration. Pyrogenalum, according to its pharmacodynamics, leads to increased concentration of IL-1 in blood, which can result in increased gene expression of iNOS [15]. At the same time we found out an increase in nitrite reductases activity that also yields NO. The elevation of nitrite reductases activity during SIRS conditions can be regarded as a protective mechanism aimed at preventing accumulation of free nitrites in periodontal tissues. Under physiological conditions nitrites get oxidized to nitrates and then are excreted with urine. Increased nitrate reductase activity in soft parodontal tissues makes this way of nitrites excretion difficult. Hence, the development of nitritive stress in the periodontal tissues is quite possible.

Reduction of antioxidant enzymes activity during SIRS modeling may develop as a consequence of depletion of these systems or "interception" of $\mathrm{O}_{2}^{--}$by nitrogen oxide with the following
$\mathrm{ONOO}^{-}$formation. The velocity rate of SOD reaction with $\mathrm{O}_{2}{ }^{-}$is $\kappa=2.0 \cdot 10^{9} \mathrm{M}^{-1} \cdot \mathrm{s}^{-1}$, while $\kappa=6.7 \cdot 10^{9} \mathrm{M}^{-1} \cdot \mathrm{s}^{-1}$ for the $\mathrm{O}_{2}{ }^{--}$reaction with $\mathrm{NO}$ [16]. Under the conditions of NO hyperproduction in periodontal tissues, a sharp rise in the $\mathrm{ONOO}^{-}$concentration confirms the possibility of "interception" of $\mathrm{O}_{2}{ }^{--}$. Increased $\mathrm{ONOO}^{-}$production can lead to the development of nitrosative stress.

$\mathrm{ONOO}^{-}$can oxidize tetrahydrobiopterin to its inactive radical leading to NOS uncoupling and subsequent $\mathrm{O}_{2}^{*-}$ production. Increased total activity of NOS indirectly proves NO hyperproduction, while increased nitrite reductases activity limits physiological NO removal. This leads to excessive levels of both $\mathrm{NO}$ and $\mathrm{O}_{2}^{-}$- which in turn leads to $\mathrm{ONOO}^{-}$ formation and creates "vicious circle".

Peroxynitrite is a powerful oxidant formed in vivo, that can directly react with different biomolecules by one (i.e. reaction with transition metals) or two-electron (i.e. reaction with thiols) oxidations. $\mathrm{ONOO}^{-}$in biological systems can react with carbon dioxide $\left(\mathrm{CO}_{2}\right)$, in equilibrium with bicarbonate $\left(\mathrm{HCO}_{3}^{-}\right)$forming ${ }^{-} \mathrm{NO}_{2}$ and $\mathrm{CO}_{3}{ }^{--}$radicals, highly oxidant species that can in turn mediate oxidative damage to biomolecules [17, 18].

Role of AP-1 inhibition in oxidative-nitrosative stress development in periodontal tissues during SIRS modeling. Blockade of AP-1 activation reduces the $\mathrm{O}_{2}{ }^{--}$production. As a mechanism that underlies this effect, we can consider the decrease in pro-inflammatory cytokines levels, which are controlled by AP-1. Tao X. et al. showed that the AP-1 inhibition by flavonoids from Rosa laevigata is accompanied by a decrease in ROS production and lowering IL-1, IL-6 and TNF- $\alpha$ expression [19]. Kankaanranta H. et al. demonstrated that TNF- $\alpha$ is capable of leading to apoptosis only under the conditions of imbalance between NF- $\kappa$ B and AP-1 [20]. The importance of a balance between transcription factors is also indicated by Fujioka S. et al. They found out that NF- $\mathrm{BB}$ activation in response to stimulation by TNF- $\alpha$, but not by IL-1, is able to inhibit AP-1 activation [21].

Jang B et al. proved that AP-1 is not directly linked to iNOS activation when lipopolysaccharides are administered [22]. However, it has been shown that AP-1 activation leads to suppression of endothelial NOS isoforms (EC 1.14.13.39, eNOS), by enhancing oxidative stress [23]. The lack of eNOS activity and oxidative stress can evoke iNOS activation. Thus we can suggest that AP-1 inhibition reduces iNOS activity by decreasing oxidation load 
and restoring the eNOS activity. In present study we did not evaluate separate activities of nNOS and eNOS, which is limitation of our study. We studied the sum of their total activities (cNOS). The absence of changes in cNOS activity during SIRS modeling can be explained by decrease in eNOS activity with simultaneous increase in nNOS activity, since AP-1 has the capacity to increase nNOS activity [24].

AP-1 controls arginase activation trough binding of Fos to the AP-1 site in the arginase 1 promoter [25]. Thus inhibition of AP-1 results in arginase activity decrease, thus lowering competition between NOS and arginases for substrate.

SIRS modeling by the introduction of bacterial lipopolysaccharide (Pyrogenalum) leads to excessive production of $\mathrm{O}_{2}^{--}$, NO and $\mathrm{ONOO}^{-}$in soft periodontal tissues. Under SIRS conditions "vicious circle" of $\mathrm{ONOO}^{-}$formation is formed. SIRS in soft periodontal tissues poses a threat of oxidative and nitrosative stress development.

Usage of AP-1 activation inhibitor SR11302 breaks "vicious circle" of ONOO' formation.

Conflict of interest. Authors have completed the Unified Conflicts of Interest form at http:// ukrbiochemjournal.org/wp-content/uploads/2018/12/ coi_disclosure.pdf and declare no conflict of interest.

\section{РОЛЬ ТРАНСКРИПЦИИНОГО ФАКТОРА АР-1 У РОЗВИТКУ ОКИСЛЮВАЛЬНО- НІТРОЗАТИВНОГО СТРЕСУ В ТКАНИНАХ ПАРОДОНТА ЗА СИСТЕМНОЇ ЗАПАЛЬНОЇ ВІДПОВІДІ}

\section{А. М. Слінська, О. С. Акімов ${ }^{\bowtie}$, \\ B. О. Костенко}

\author{
ВДНЗУ «Українська медична \\ стоматологічна академія», Полтава; \\ 凶e-mail: riseofrevan5@gmail.com
}

Хронічна системна запальна відповідь (SIRS) лежить в основі багатьох захворювань (сепсис, атеросклероз, цукровий діабет). За даними наукових досліджень останніх років в розвитку SIRS ключову роль відіграє активація різних ядерних транскрипційних факторів. Розглянуто вплив транскрипційного фактора - активаторного протеїну 1 (АР-1) - на розвиток окислювальнонітрозативного стресу в м'яких тканинах паро- донта за хронічної системної запальної відповіді (SIRS). Експеримент проведено на 24 щурах лінії Вістар. SIRS моделювали шляхом введення бактеріального ліпополісахариду Salmonella typhi $(0,4$ мкг/кг, внутрішньоочеревинно). В гомогенаті м'яких тканин пародонта визначали зміни у функціонуванні циклу оксиду азоту (NO), продукцію супероксидного аніонрадикала $\left(\mathrm{O}_{2}^{*-}\right)$ і активність антиоксидантних ензимів. Як інгібітор АР-1 використовували SR11302 (15 мг/кг) протягом 2 місяців. Встановлено, що у разі моделювання SIRS в м'яких тканинах пародонта відбувається зниження активності антиоксидантних ензимів $з$ одночасним збільшенням продукції $\mathrm{O}_{2}{ }^{\circ}$. SIRS підвищує продукцію NO від індуцибельної NO-синтази (iNOS) i нітрит-редуктаз. Неокислювальне розщеплення L-аргініну в умовах SIRS також зростає. Концентрація пероксинітриту (ONOO-) збільшується в 2,1 раза. Інгібування АР-1 за допомогою SR11302 нормалізує функціонування циклу $\mathrm{NO}$, знижує продукцію $\mathrm{O}_{2}{ }^{--}$і відновлює активність антиоксидантних ензимів. Таким чином, в умовах SIRS формується «порочне коло» 3 продукції ONOO-. SIRS створює загрозу розвитку оксидативного і нітрозативного стресу в м'яких тканинах пародонта. Використання інгібітора активації AP-1 SR11302 розриває «порочне коло» продукції ONOO-

К л ю чов і с лов а: пародонт, с системна запальна відповідь, активаторний протеїн 1 (AР-1), супероксидний аніон-радикал, цикл оксиду азоту.

\section{References}

1. Bone RC, Sibbald WJ, Sprung CL. The ACCPSCCM consensus conference on sepsis and organ failure. Chest. 1992; 101(6): 1481-1483.

2. Gerasymenko ND. The role of systemic inflammation and peroxisome proliferatoractivated receptors, in the pathogenesis of hypertension. Bull Probl Biol Med. 2015; 120(3): 16-19. (In Russian).

3. Bayani M, Pourali M, Keivan M. Possible interaction between visfatin, periodontal infection, and other systemic diseases: A brief review of literature. Eur J Dent. 2017; 11(3): 407410.

4. Li X, Peng H, Wu J, Xu Y. Brain natriuretic peptide-regulated expression of inflammatory 
cytokines in lipopolysaccharide (LPS)-activated macrophages via NF- $\kappa \mathrm{B}$ and mitogen activated protein kinase (MAPK) pathways. Med Sci Monit. 2018; 24: 3119-3126.

5. Yelins'ka AM, Shvaykovs'ka OO, Kostenko VO. Sources of production of reactive oxygen and nitrogen species in tissues of periodontium and salivary glands of rats under modeled systemic inflammation. Probl Ekol Med. 2017; 21(3-4): 51-54.

6. Akimov OY, Kostenko VO. Functioning of nitric oxide cycle in gastric mucosa of rats under excessive combined intake of sodium nitrate and fluoride. Ukr Biochem J. 2016; 88(6): 70-75.

7. Kostenko VO, Tsebrzhins'kii OI. Production of superoxide anion radical and nitric oxide in renal tissues sutured with different surgical suture material. Fiziol Zh. 2000; 46(5): 56-62. (In Ukrainian).

8. Kaidashev IP. Methods of clinical and experimental research in medicine. Poltava: Polimet, 2003. 319 p. (In Ukrainian).

9. Koroliuk MA, Ivanova LI, Mayorova IG, Tokarev VE. A method of determining catalase activity. Lab Delo. 1988; (1): 16-19. (In Russian).

10. Rabelo LA, Ferreira FO, Nunes-Souza V, da Fonseca LJ, Goulart MO. Arginase as a critical prooxidant mediator in the binomial endothelial dysfunction-atherosclerosis. Oxid Med Cell Longev. 2015; 2015: 924860.

11. Mori M. Regulation of nitric oxide synthesis and apoptosis by arginase and arginine recycling. J Nutr. 2007; 137(6 Suppl 2): 1616S-1620S.

12. Förstermann U, Sessa WC. Nitric oxide synthases: regulation and function. Eur Heart J. 2012; 33(7): 829-837.

13. Cao Y, Zhang X, Shang W, Xu J, Wang X, Hu X, Ao Y, Cheng H. Proinflammatory cytokines stimulate mitochondrial superoxide flashes in articular chondrocytes in vitro and in situ. PLoS One. 2013; 8(6): e66444.

14. Barbieri SS, Amadio P, Gianellini S, Zacchi E, Weksler BB, Tremoli E. Tobacco smoke regulates the expression and activity of microsomal prostaglandin E synthase-1: role of prostacyclin and NADPH-oxidase. FASEB J. 2011; 25(10): 3731-3740.

15. Burke SJ, Updegraff BL, Bellich RM, Goff MR, Lu D, Minkin SC Jr, Karlstad MD, Collier JJ. Regulation of iNOS gene transcription by IL$1 \beta$ and IFN- $\gamma$ requires a coactivator exchange mechanism. Mol Endocrinol. 2013; 27(10): 17241742.

16. Starodubtseva MN. Dual role of peroxynitrite in organism. Probl Health Ecology. 2004; 1: 35-41. (In Russian).

17. Bartesaghi S, Radi R. Fundamentals on the biochemistry of peroxynitrite and protein tyrosine nitration. Redox Biol. 2018; 14: 618-625.

18. Radi R. Peroxynitrite reactions and diffusion in biology. Chem Res Toxicol. 1998; 11(7): 720-721.

19. Tao X, Sun X, Xu L, Yin L, Han X, Qi Y, Xu Y, Zhao Y, Wang C, Peng J. Total flavonoids from Rosa laevigata Michx fruit ameliorates hepatic ischemia/reperfusion injury through inhibition of oxidative stress and inflammation in rats. Nutrients. 2016; 8(7). pii: E418.

20. Kankaanranta $H$, Ilmarinen $P$, Zhang $X$, Adcock IM, Lahti A, Barnes PJ, Giembycz MA, Lindsay MA, Moilanen E. Tumour necrosis factor- $\alpha$ regulates human eosinophil apoptosis via ligation of TNF-receptor 1 and balance between NF-אB and AP-1. PLoS One. 2014; 9(2): e90298.

21. Fujioka S, Niu J, Schmidt C, Sclabas GM, Peng B, Uwagawa T, Li Z, Evans DB, Abbruzzese JL, Chiao PJ. NF-kappaB and AP-1 connection: mechanism of NF-kappaB-dependent regulation of AP-1 activity. Mol Cell Biol. 2004; 24(17): 7806-7819.

22. Jang B, Ishigami A, Kim YS, Choi EK. The peptidylarginine deiminase inhibitor $\mathrm{Cl}$-amidine suppresses inducible nitric oxide synthase expression in dendritic cells. Int J Mol Sci. 2017; 18(11). pii: E2258.

23. González-Rubio S, Linares CI, Aguilar-Melero P, Rodríguez-Perálvarez M, Montero-Álvarez JL, de la Mata M, Ferrín G. AP-1 Inhibition by SR 11302 protects human hepatoma HepG2 cells from bile acid-induced cytotoxicity by restoring the NOS-3 expression. PLoS One. 2016; 11(8): e0160525.

24. Chan CF, Sun WZ, Lin JK, Lin-Shiau SY. Activation of transcription factors of nuclear factor kappa B, activator protein-1 and octamer factors in hyperalgesia. Eur J Pharmacol. 2000; 402(1-2): 61-68.

25. Sharda DR, Yu S, Ray M, Squadrito ML, De Palma M, Wynn TA, Morris SM Jr, Hankey PA. Regulation of macrophage arginase expression and tumor growth by the Ron receptor tyrosine kinase. J Immunol. 2011; 187(5): 2181-2192. 